\title{
Simulation of Photovoltaic Power System for Rural Electrification in Myanmar
}

\author{
Alexander V. Bobyl ${ }^{1}$, \\ Dr.Sc.(Phys.-Math.), full professor, \\ e-mail: bobyl@theory.ioffe.ru; \\ Georgiy A. Konoplev², \\ Ph.D.(Eng.), associate professor, \\ e-mail: gakonoplev@etu.ru;
}

\author{
Htein Htein Lin', \\ master student, e-mail: hteinhteinlin95@gmail.com; \\ Andrey F. Erk ${ }^{3}$, \\ Ph.D.(Eng.), senior research fellow, \\ e-mail: 4666866@bk.ru
}

${ }^{1}$ Ioffe Institute, Saint Petersburg, Russian Federation;

${ }^{2}$ Saint Petersburg Electrotechnical University “LETI", Saint-Petersburg, Russian Federation;

${ }^{3}$ Institute of Engineering and Environmental Problems - branch of FSAC VIM, Saint Petersburg, Russian Federation

\begin{abstract}
In the recent years substantial growth of the demand for electricity took place in Myanmar; energy generation by existing sources (mainly hydropower) is not enough to provide constantly increasing consumption. The problem is most obvious in rural areas (more than 61 percent of the population) where grid extension is not justified economically whereas the cost of electricity produced by autonomous diesel generators is extremely high. (Research purpose) The purpose of this research is the evaluation of economic and technical feasibility of small off-grid (standalone) photovoltaic (PV only) and hybrid photovoltaicdiesel (PV-diesel) power generation systems providing rural household electricity consumption in Myanmar. (Materials and methods) Computer simulation using Homer pro simulation software was used. Three different load scenarios were envisaged low, medium and high (1; 6 and 16 kilowatt-hour per day). Simulation was done for Tha Ngar village tract with a population of about 3,000 people, which is typical in Myanmar. (Results and discussion) The results of the simulation reveal that the levelized cost of energy (LCOE) for optimal hybrid (PV-diesel) systems lies in the range 0.37-0.51 US\$, for PV only systems - 0.46-0.49 US\$. It proves their economic feasibility compared to conventional diesel generator systems with LCOE 0.56-1.56 US\$ boosted by high fuel prices in remote areas (2-3 times higher than urban price). For the high load scenario hybrid systems are more preferable, for low load (night time lighting only) PV only systems may be more effective. (Conclusions) It can be concluded that implementing solar energy is not only environmentally friendlier but also economically justified approach for providing household electricity demands of rural settlements in Myanmar without constructing expensive grid extensions.
\end{abstract}

Keywords: photovoltaics, off-grid solar systems, rural electrification, Myanmar, computer simulation, feasibility study.

For citation: Bobyl A.V., Konoplev G.A., Lin H.H., Erk A.F. Simulation of photovoltaic power system for rural electrification in Myanmar. Sel'skokhozyaystvennye mashiny i tekhnologii. 2020. Vol. 14. N2. 4-9 (In English). DOI 10.22314/2073-7599-2020-14-2-4-9.

\section{Моделирование солнечной электростанции для электрификации сельских районов Мьянмы}

\author{
Александр Васильевич Бобыль ${ }^{1}$, \\ доктор физико-математических наук, \\ професcop, e-mail: bobyl@theory.ioffe.ru; \\ Георгий Асадович Коноплев ${ }^{2}$, \\ кандидат технических наук, доцент, \\ e-mail: gakonoplev@etu.ru;
}

\author{
Хтеин Хтеин Лин², \\ студент-магистрант, \\ e-mail: hteinhteinlin95@gmail.com; \\ Андрей Федорович Эрк³, \\ кандидат технических наук, старший научный \\ сотрудник, e-mail: 4666866@bk.ru
}

\footnotetext{
${ }^{1}$ Физико-технический институт имени А.Ф. Иоффе, Санкт-Петербург, Российская Федерация; ${ }^{2}$ Санкт-Петербургский государственный электротехнический университет «ЛЭТИ», Санкт-Петербург, Российская Федерация;

${ }^{3}$ Институт агроинженерных и экологических проблем сельскохозяйственного производства (ИАЭП) филиал ФНАЦ ВИМ, Санкт-Петербург, Российская Федерация
}

Реферат. В последние годы существенный рост потребления электроэнергии в Мьянме уже не может быть удовлетворен за счет существующих источников генерации, главным образом гидроэлектростанций. Особенно остро проблема стоит в 
сельских районах, где проживает более 61 процента населения страны: подключение к централизованным электрическим сетям экономически не оправдано, а стоимость электроэнергии, вырабатываемой автономными дизельными генераторами, очень высока. (Цель исследования) Оценить технико-экономическую целесообразность создания и использования солнечных и гибридных солнечно-дизельных малых автономных электростанций для обеспечения базовых потребностей домохозяйств в сельских поселениях Мьянмы. (Материаль и методы) Использовали метод компьютерного моделирования в специализированной программе Homer pro. Проанализировали три сценария энергопотребления: низкий - 1 киловатт-час в день, средний - 6 киловатт-часов и высокий - 16 киловатт-часов. Моделирование проводили на примере типичного для страны сельского поселения Та Нгар с населением 3000 человек. (Результаты и обсуждение) Определили, что нормированная стоимость электроэнергии для оптимизированных гибридных систем лежит в диапазоне 0,37-0,51 доллара США, для чисто фотовольтаических электростанций - 0,46-0,49 доллара. Выявили более высокую экономическую эффективность гибридных систем по сравнению с дизельными генераторами, для которых нормированная стоимость электроэнергии составляет 0,56-1,56 доллара США с учетом сложившихся цен на топливо в отдаленных районах страны, которые превышают городские цены в 2-3 раза. Показали, что при высоком энергопотреблении предпочтительнее использование гибридных систем, для малого потребления (только ночное освещение) более эффективны чисто фотовольтаические. $(B b l b o d b l)$ Доказали, что для удовлетворения потребностей в электроэнергии сельских поселений в Мьянме целесообразно использование солнечной энергии, что обусловлено не только экологически, но и экономически, так как исключает необходимость дорогостоящего подключения к электрическим сетям.

Ключевые слова: фотовольтаика, автономные солнечные электростанции, электрификация сельских районов, Мьянма, компьютерное моделирование, технико-экономическое обоснование.

Ш Для цитирования: Бобыль А.В., Коноплев Г.А., Лин Х.Х., Эрк А.Ф. Моделирование солнечной электростанции для электрификации сельских районов Мьянмы // Сельскохозяйственнье машинь и технологии. 2020. T. 14. N2. C. 4-9. DOI 10.22314/2073-7599-2020-14-2-4-9.

$\mathrm{M}$ yanmar, one of the Southeast Asian Nations is located between latitudes $09^{\circ} 32^{\prime} \mathrm{N}$ and $28^{\circ} 31^{\prime} \mathrm{N}$ and longitudes $92^{\circ} 10^{\prime} \mathrm{E}$ and $101^{\circ} 11^{\prime} \mathrm{E}$ with an area of 677,000 square kilometers with population over 52 million which expected to grow to 64 million, while the average per capita electricity demand rises from 0.3 to $0.7 \mathrm{MWh}$ before 2050 [1]. Electricity demand of the country has been increasing every year especially in rural area. Therefore, almost all possible energy sources should be considered for Myanmar. Myanmar electricity production capacity is only around $3000 \mathrm{MW}$ which depends mainly on hydropower. Natural gas, coal and other energy sources are also used.

Rural electrification become a major problem for Myanmar [2]. According to the data of Ministry of Electricity and Energy, 2020, only 50\% of total households in Myanmar have access to electricity and most of them are located in urban area. In Myanmar, $70 \%$ of total population lives in rural area so electricity access to them is very important [3]. Moreover, $61 \%$ of the country population lives in village tracts whose have a population just between 1000 and 10000 and approximately 10346 (76\%) of total 13620 villages tracts have that kind of population (Table 1).

The table clearly indicated that how rural electrification is very important in Myanmar. Population data is also one of the most important data of GIS for preplanning solar energy such as choosing priorities. According to GIS data from Myanmar Information Management Unit in 2019, some villages of Myanmar have been classified as "Hard to reach villages". Solar energy may be suitable for those places. Tha Nga village is also one of these kinds of

\begin{tabular}{|l|c|c|}
\hline \multicolumn{3}{|c|}{$\begin{array}{c}\text { VILLAGES AND THEIR TOTAL POPULATION } \\
\text { BY STATE AND REGION OF MYANMAR (2014) }\end{array}$} \\
\hline State / Region & $\begin{array}{c}\text { Villages } \\
\text { (1000-10000 people) }\end{array}$ & Total population \\
\hline Kachin State & 224 & 667,023 \\
\hline Kayah State & 56 & 102,973 \\
\hline Kayin State & 308 & $1,034,871$ \\
\hline Chin State & 130 & 202,095 \\
\hline Sagaing Region & 1467 & $4,025,041$ \\
\hline Tanintharyi Region & 216 & 785,379 \\
\hline Bago Region & 1234 & $3,495,704$ \\
\hline Magway Region & 1149 & $2,989,953$ \\
\hline Mandalay Region & 1194 & $3,475,107$ \\
\hline Mon State & 329 & $1,189,042$ \\
\hline Rakhine State & 641 & $1,480,655$ \\
\hline Yangon Region & 515 & $1,459,406$ \\
\hline Shan State & 982 & $3,066,365$ \\
\hline AyeyarwadyRegion & 1729 & $5,888,948$ \\
\hline Nay Pyi Taw* & 172 & 665,855 \\
\hline Total & $10346(76 \%)$ & $30,528,417(61 \%)$ \\
\hline *Capital, Union territory of Myanmar & \\
\hline
\end{tabular}

villages that have many challenges to be electrified such as deficiency in electric transmission lines, bad transportation etc. For example, villages in less densely populated area which are located very far away from urban centers are usually considered not cost-effective for grid connections. So off-grid, mini-grid methods have to be con- 
sidered and Solar Photovoltaic (PV) can be a perfect solution in this case taking into account high solar energy resources in Myanmar [4, 5].

The highest Global Horizontal Irradiance (GHI) is identified in the central, lowland area of the country, where average daily totals reach yearly total of $1900 \mathrm{kWh} / \mathrm{m}^{2}$ (average daily total up to $5.2 \mathrm{kWh} / \mathrm{m}^{2}$ ) or higher. Further north, GHI values falls between 1400 and $1600 \mathrm{kWh} / \mathrm{m}^{2}$ (average daily total from $3.8 \mathrm{kWh} / \mathrm{m}^{2}$ up to $4.4 \mathrm{kWh} / \mathrm{m}^{2}$ ). Minimum GHI values in northernmost part of the country are lower than $1300 \mathrm{kWh} / \mathrm{m}^{2}$ (average daily total approx. $3.6 \mathrm{kWh} / \mathrm{m}^{2}$ ), yet the solar resource in these areas is still sufficiently high.

According to the map (Fig. 1), the average yearly total of specific $\mathrm{PV}$ power production varies between 1150 $\mathrm{kWh} / \mathrm{kWp}$ (equals to average daily total of about 3.2 $\mathrm{kWh} / \mathrm{kWp}$ ) and $1600 \mathrm{kWh} / \mathrm{kWp}$ (about $4.4 \mathrm{kWh} / \mathrm{kWp}$ daily) with high values in the central region (Fig. 1). In mountains, the power production is lower by up to $20 \%$ or even more, due to terrain shading (Suri M. et al., 2017).

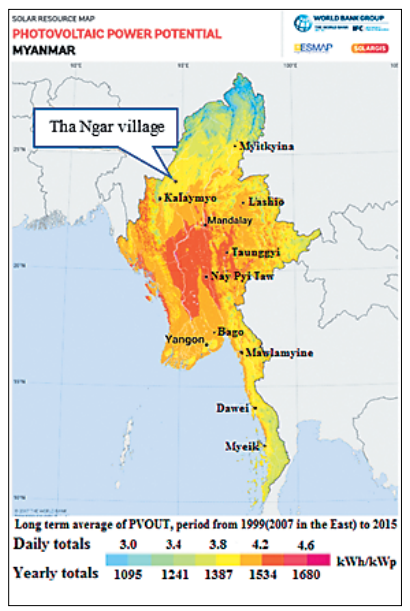

Fig. 1. Solar photovoltaic potential in Myanmar and site location

According to the national electrification plan, PV will also be one of the important energy sources in Myanmar. It is aimed to reach $5 \%$ of total electricity production in 2030. First Myanmar PV solar power plant, $170 \mathrm{MW}$ will start production in summer, 2020.

RESEARCH PURPOSE is the evaluation of economic and technical feasibility of small off-grid (standalone) photovoltaic (PV only) and hybrid photovoltaic-diesel (PV-diesel) power generation systems providing rural household electricity consumption in Myanmar.

Materials AND METHODS. In applying solar energy system in rural area, there are lots of things have to be considered to predict the economic feasibility of PV installations. The best way to make such predictions is preliminary computer simulations with dedicated software tools (Homer pro, RETscreen, etc.) [6, 7]. We evaluated economic and technical feasibility of off-grid (standalone) PV systems for a Village Tract of Myanmar called Tha Ngar using Homer pro software. Its location is $23^{\circ} 58^{\prime} 25.0^{\prime \prime}$
N 9436'24.5" E. It has population of 2959 living in 439 households. Tha Ngar is $10 \mathrm{~km}$ away from the nearest road and $68 \mathrm{~km}$ away from grid which will make it to be the last priority in national electrification plan.

For simulation we used climate data provided by NASA. Daily solar radiation ranged from 3.7 to $5.6 \mathrm{kWh} / \mathrm{m}^{2} / \mathrm{d}$. Wind speed was between 0.8 and $1.2 \mathrm{~m} / \mathrm{s}$ (Fig. 2). Relative humidity was $\min 39 \%$ and $\max 66 \%$. Air temperature was minimum $17^{\circ} \mathrm{C}$ in January and maximum $28.9^{\circ} \mathrm{C}$ in June.

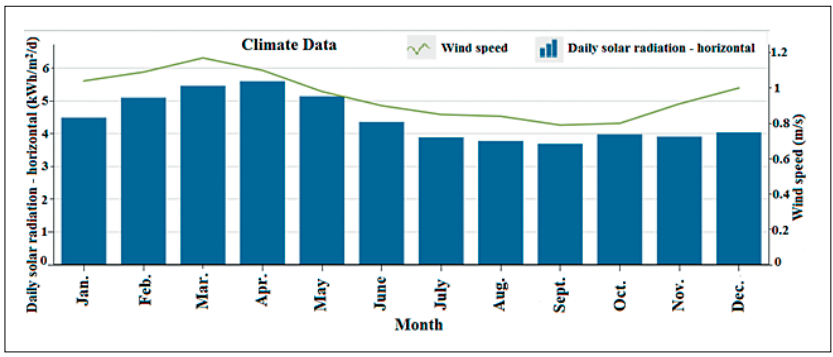

Fig. 2. Daily solar radiation and wind speed at Tha Ngar village

Three different load scenarios which match the real needs and situations of rural area of Myanmar were prepared (Tables 2-4).

\begin{tabular}{|c|c|c|c|c|}
\hline \multicolumn{5}{|c|}{ LOW CONSUMPTION } \\
\hline $\begin{array}{l}\text { Electrical } \\
\text { appliances }\end{array}$ & 芯 & 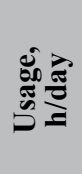 & 离 & 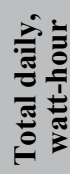 \\
\hline Incandescent & 2 & 6 & 60 & 720 \\
\hline $\begin{array}{l}\text { Compact } \\
\text { fluorescent }\end{array}$ & 1 & 12 & 11 & 132 \\
\hline Portable lamp & 2 & 6 & 20 & 240 \\
\hline Total & - & - & - & 1092 \\
\hline
\end{tabular}

\begin{tabular}{|c|c|c|c|c|}
\hline \multicolumn{5}{|c|}{ Medium Consumption } \\
\hline $\begin{array}{l}\text { Electrical } \\
\text { appliances }\end{array}$ & 总 & 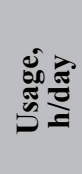 & 离 & 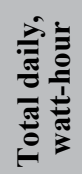 \\
\hline Incandescent & 4 & 12 & 60 & 2880 \\
\hline $\begin{array}{l}\text { Compact } \\
\text { fluorescent }\end{array}$ & 2 & 12 & 11 & 264 \\
\hline Portable lamp & 2 & 6 & 20 & 240 \\
\hline Mobile phone & 1 & 6 & 12 & 72 \\
\hline TV & 1 & 3 & 60 & 180 \\
\hline Refrigerator & 1 & 24 & 100 & 2400 \\
\hline Total & - & - & - & 6036 \\
\hline
\end{tabular}




\begin{tabular}{|c|c|c|c|c|}
\hline \multicolumn{5}{|c|}{ HIGH CONSUMPTION } \\
\hline $\begin{array}{c}\text { Electrical } \\
\text { appliances }\end{array}$ & 氖 & 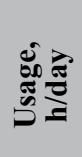 & 离 & 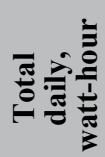 \\
\hline $\begin{array}{l}\text { Medium } \\
\text { consumption }\end{array}$ & - & - & - & 6036 \\
\hline $\begin{array}{l}\text { Average } \\
\text { modern stove }\end{array}$ & 1 & 3 & 1500 & 4500 \\
\hline Air conditioner & 1 & 3 & 1000 & 3000 \\
\hline Water pump & 1 & 3 & 750 & 2250 \\
\hline Laptop & 1 & 6 & 70 & 420 \\
\hline Total & - & - & - & 16,206 \\
\hline
\end{tabular}

Low consumption (LC) is night only lighting purpose, generally from 4 to 7 am and 6 to $9 \mathrm{pm}$ (Table 2). Total daily consumption is around $1.092 \mathrm{kWh} /$ day. In most rural village, the minimum load hours can be reduced to 6 hours daily. In village life, it is still "early to bed and early to rise". They wake up before 4 am and prepare for their work. So, this period is important for them to get light. Medium consumption (MC) aims for more than lighting purpose but still prefer small load. Load is $6.036 \mathrm{kWh} /$ day (Table 3). High consumption (HC) will be functional household usage with $16.206 \mathrm{kWh} /$ day (Table 4). But it still can be said not much load comparing to urban usage.

These scenarios are flexible and can be change depending on regions and needs. These load scenarios were calculated based on information taken from some research and surveys in Myanmar (Myint A.K., Ya A.Z., Ohn S.S., Aung S.M., 2018).

Using Homer pro, assessment tool for hybrid renewable electric generation systems, analyzing was done. Two systems, PV only and Hybrid (PV-Diesel), were compared for each scenario. Generally, a PV system should have some backup generation because there are certain conditions when PV generation can be unavailable (due to weather, maintenance etc.). But here it was simulated without a backup generator in order to compare costs for PV only and Hybrid systems. Moreover, in some cases, such as LC, where load is very small and only aim for lighting purpose thus it is also possible not to use backups like a diesel generator.

Moreover, it is important to apply best parameters; system components and design, their costs and efficiency which have to be similar to the real costs on the local market (in this case, Myanmar). Depending on the input data, the simulation results can be different, but they were always rechecked by comparing with other external data.

RESULTS AND DISCUSSION. In total six possible system options, two different types (PV only and hybrid) for each load consumption scenario were simulated.

The system architecture requires to meet three load scenarios (LC, MC, and $\mathrm{HC}$ ) in the most optimal way

\begin{tabular}{|l|c|c|c|}
\hline \multicolumn{4}{|c}{ System ARCHITECTURE REQUIREMENT, $\mathrm{kW}$} \\
\hline \multirow{2}{*}{$\begin{array}{c}\text { Consumption } \\
\text { system }\end{array}$} & \multicolumn{2}{|c|}{ Hybrid } & \multirow{2}{*}{ PV only } \\
\cline { 2 - 3 } & Diesel & PV & \\
\hline Low & $0.35(0.5)$ & 0.118 & 0.70 \\
\hline Medium & 1.00 & 0.70 & 3.11 \\
\hline High & 4.50 & 2.00 & 8.50 \\
\hline
\end{tabular}

(Table 5). More solar panels were needed in the PV only system. It was also possible to reduce the number of solar panels that we used in Hybrid systems just by increasing time of using diesel generator when fuel price become lower and advantage was that it was no need to increase diesel generator system capacity (same generators). As maximum, $8.5 \mathrm{~kW}$ PV panels were needed to cover total usage of $16 \mathrm{kWh} /$ day in $\mathrm{HC}$ scenario of PV only system.

Even in the hybrid system, diesel generator output should be lower than PV output of that system in order to get lower costs for high fuel price. Simulation result recommended less diesel usage even in hybrid system because of its cost (initial cost, fuel cost). This is because generally, in rural area of Myanmar the fuel cost always more than the urban price. In places where transportation conditions are very bad, the fuel price usually can be double or even triple of urban price.

We can see effects of fuel price and nominal discount rate (Fig. 3). Lower nominal rate and higher fuel price made PV system more desirable. At many rural places of Myanmar, the fuel cost is more than urban price. Therefore, PV system will be more preferable for rural area including this village.

Another important fact to be considered was levelized cost of energy (LCOE). This indicator shows range from 0.369 US\$ to 0.511 US\$ for the Hybrid system and range from 0.46 US\$ to 0.49 US\$ for the PV only system (Fig. 4). Both systems have better LCOE than "diesel only" system which was still more expensive even at the urban fuel price. The price of fuel in this villages was $1.34 \$ / \mathrm{L}$ which was double of the urban price. This price also depended on many factors such as difficult transportation, importing components, etc. Other than that, one important fact was energy storage cost.

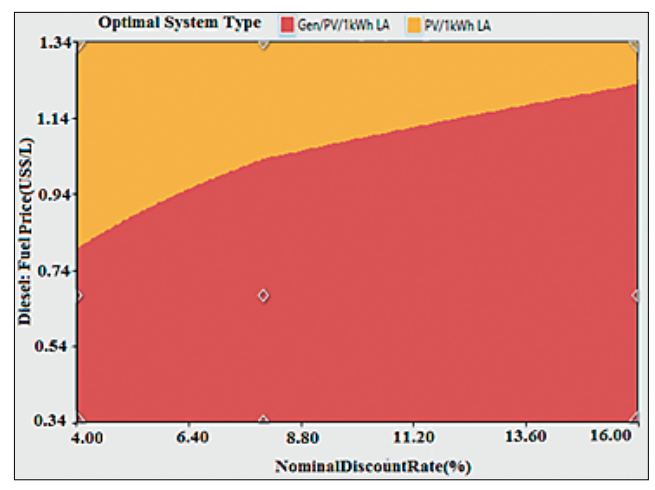

Fig. 3. Optimal system type depending on fuel price 


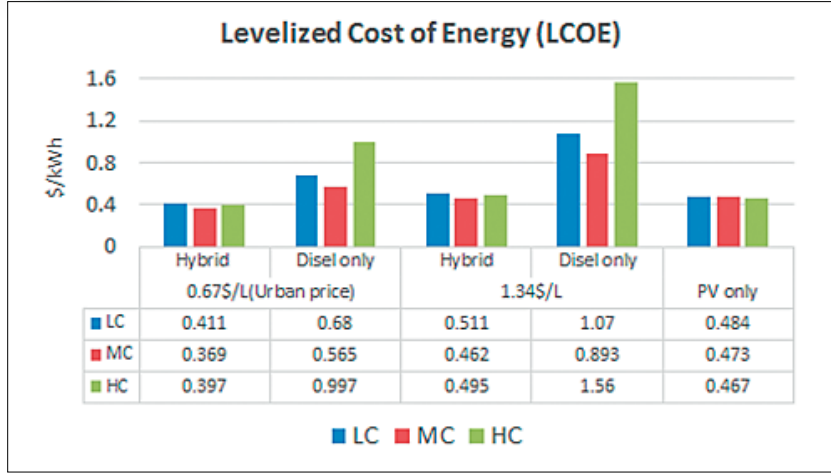

Fig. 4. Levelized cost of energy for different generation structures

In Myanmar, lead acid batteries are still being used as energy storage for PV system despite the fact that they are expensive and have some failures such as voltage drops, very short life (sometimes less than 20 months) [3]. The price in this simulation is $180 \mathrm{US} \$ / \mathrm{kWh}$ with replacement cost $145 \mathrm{US} \$ / \mathrm{kWh}$. But now it is recommended to use lithium-ion batteries which have more life time and better quality than lead acid and whose price has been falling (in 2020, the price estimated to drop around 124.24 $\mathrm{US} \$ / \mathrm{kWh}$ ). This will definitely have positive effect on LCOE. With reducing battery and PV cost LCOE of PV can reach around 0.2 US\$ per kWh or even lower.

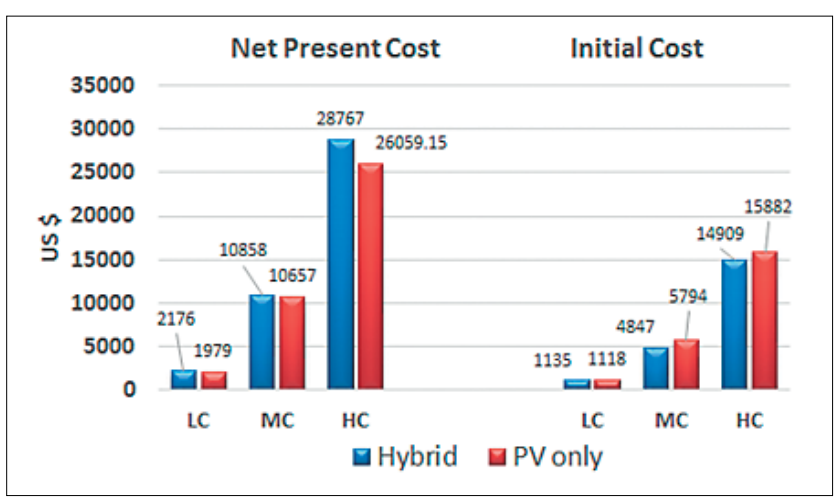

Fig. 5. Net present and initial cost comparisons

Net present cost of all PV only scenarios were cheaper than that of Hybrid systems because of high fuel price in rural areas while initial cost of Hybrid systems was cheaper than PV only except LC scenario (Fig. 5). Overall, we can conclude that PV systems (both PV only and Hybrid) are cost effective and could be implemented as an economically justified solution for electrification of rural area in Myanmar.

For further alternative ways related to PV although not analyzed in this paper, there are also good potential for other solar hybrid systems (solar + wind, solar + biomass) [8]. As reported by Asian development bank, not only offgrid system but also mini-grid and on-grid system may be considered $[9,10]$.

Conclusion. According to the simulation results, PV only systems are a little more expensive than hybrid systems in terms of initial cost. Initial cost for three scena- rios of PV only are 1118 \$, 5794 \$, and 15882 \$ while those of hybrid are $1135 \$, 4847$ \$, and 14909 \$ respectively. We should also be aware that initial cost of hybrid does not include the cost of fuel that will be consumed in total system life time. Both PV only and Hybrid costs are almost the same because the amount of PV panels used in both systems also almost the same. PV only may be a little cheaper than Hybrid but Hybrid has an advantage that it can be more reliable. For example, some unexpected days where PV output largely decrease due to weather. But both systems were surely better than ones depending only on diesel generators.

Because in this research only one location has been considered, it was difficult to cover details of all rural areas in Myanmar. But most fundamentals and backgrounds are similar so that we can adopt this for considering other villages or rural settlements of Myanmar in future. Moreover, in rural electrification, it can be implemented not only for household usage but also for others such as worship places (pagodas, monasteries), educational institutions (mainly primary schools), small businesses, agriculture related usage (irrigation) etc. Almost all villages in Myanmar have above places at least one or more and they also need electricity.

PV systems can be recommended as one of the reliable energy sources of Myanmar and other regions with close climatic and socio-economic conditions. It will be more suitable in future because of price falling and technologies development.

\section{Acknowledgement}

Special thanks to Dmitriy Bogdanov and Christian Breyer for allowing us to use presentation "Global 100\% RE System: Southeast Asia-Myanmar". 


\section{REFERENCES}

1. Bogdanov D., Farfan J., Sadovskaia K., et al. Radical transformation pathway towards sustainable electricity via evolutionary steps. Nature Communications. 2019. Vol. 10. 1077 (In English).

2. Ismailetal A.M. et al. Progress of solar photovoltaic in ASEAN countries: A review. Renewable and Sustainable Energy Reviews. 2015. Vol. 48. 399-412 (In English).

3. Kim H., Jung T.Y. Independent solar photovoltaic with Energy Storage Systems (ESS) for rural electrification in Myanmar Renewable and Sustainable. Energy Reviews. 2018. Vol. 82. 1187-1194 (In English).

4. Newcombe A., Ackom E.K. Sustainable solar home systems model: Applying lessons from Bangladesh to Myanmar's rural poor. Energy for Sustainable Development. 2017. Vol. 38. 21-33 (In English).

5. Janjai S. et al. Satellite-derived solar resource maps for Myanmar. Renewable Energy. 2013. Vol. 53. 132-140 (In English).

6. Yuan J. et al. A method to estimate the potential of rooftop

Конфликт интересов. Авторы заявляют об отсутствии конфликта интересов. photovoltaic power generation for a region. Urban Climate. 2016. Vol. 17. 1-19 (In English).

7. Siala K., Stich J. Estimation of the PV potential in ASEAN with a high spatial and temporal resolution. Renewable Energy. 2016. Vol. 88. 445-456 (In English).

8. Sandar L., Aung Z.Ya. Solar/Wind/Desel Hybrid Energy System with Battery Storage for Rural Electrification. International Journal of Scientific Engineering and Technology Research. 2014. Vol. 3. N10. 2172-2176 (In English).

9. Toktarova A. et al. Long term load projection in high resolution for all countries globally. Electrical Power and Energy Systems. 2019. Vol. 11. 160-181 (In English).

10. Gulagi A., Bogdanov D., Breyer C. A Cost Optimized Fully Sustainable Power System for Southeast Asia and the Pacific Rim. Energies. 2017. Vol. 10. 583 (In English).

Conflict of interest. The authors declare no conflict of interest. 